G.I. Khovanets', O.Yu. Makido, Yu.G. Medvedevskikh, I.Yu. Yevchuk

\title{
THE INFLUENCE OF POLYMERIC MATRIX STRUCTURE ON THE KINETIC AND THERMOMECHANICAL PROPERTIES OF ORGANIC-INORGANIC COMPOSITES BASED ON TEOS
}

\author{
Department of Physical Chemistry of Fossil Fuels of the Institute of Physical-Organic Chemistry and Coal \\ Chemistry named after L.M. Lytvynenko of the National Academy of Sciences of Ukraine \\ 3a, Naukova Str., Lviv, 79060,Ukraine,_E-mail: khovanets_galyna@ukr.net
}

\begin{abstract}
A promising trend in modern material science is the development of new composite materials based on organicinorganic systems with unique characteristics that combine the properties of individual components. Hybrid organicinorganic composites based on the system of mono- or dimethacrylate and tetraethoxysilane (TEOS) were synthesized. The influence of the structure of the polymer matrix (2-hydroxyethyl methacrylate (HEMA) or oligoesteracrylate (MGF-9)) and the composition of relates hybrid systems on thermomechanical properties and molecular structure of the resulting composites and kinetics of polymerization till deep conversion has been studied. The synthesis of composites was carried out via the process of simultaneous polymerization of the mixtures of liquid organic and inorganic components, during which the inorganic structure is formed in situ in the polymer matrix. The kinetics of stationary photoinitiated polymerization of monomer-tetraethoxysilane systems in thin films till deep conversion was investigated by laser interferometry. The experimental integral and differential kinetic curves were obtained and kinetic parameters of photoinitiated polymerization of the studied systems were determined. As a result, the dependence of the values of the maximum rate of polymerization, conversion and time of its achievement on the ratio monomer : tetraethoxysilane in the compositions was revealed. The kinetic features of polymerization of mono- and dimethacrylates were described using the concept of microheterogeneity of the process of photoinitiated polymerization till deep conversion. The thermomechanical analysis determined the characteristic temperatures, the values of the thermomechanical structural-molecular parameters of the composites were calculated as well. It was shown that when introducing an inorganic filler into a matrix of monomethacrylate, the linear growth of the thermomechanical stability of the material can be observed depending on the quantity of TEOS, while in the case of dimethacrylate matrix this dependence can be characterized by the presence of an extremum, which is related to the formed composites. It was found that HEMA :TEOS = 95:5 vol. \% and MGF-9:TEOS $=90: 10$ vol. $\%$ composites have the improved thermomechanical properties.

The obtained composites can be perspective for the use as a protective coating, in particular for solar collectors, and a basis for the manufacture of conductive membranes for fuel cells.
\end{abstract}

Keywords: organic-inorganic composite, sol-gel system, photoinitiated polymerization, kinetics of polymerization till deep conversion, thermomechanical analysis

\section{INTRODUCTION}

The perspective direction in modern material science is the development of new composite materials based on organic-inorganic systems. Successfully combining organic and inorganic components of the system, changing components ratio and synthesis conditions, one can "sum" the properties of individual components in the resulting composites, thereby improving their performance or obtaining new unique properties. Hybrid organic-inorganic composites (HOIC) are promising as protective coatings, polymeric electrolytes, membranes for use in medicine, optics, microelectronics, etc. [1].

One of the widened methods of obtaining $\mathrm{HOIC}$ is formation them in the process of joint polymerization of the mixture of liquid organic and inorganic components. When using sol-gel technology, inorganic and organic components are combined by covalent or physical interactions forming composite materials with an even distribution of inorganic component in organic matrix and the absence of essential phase segregation [2]. The use of silica fillers leads to improved physical and mechanical characteristics (thermal stability, water resistance, resistance to temperature difference and solar radiation) and increase in durability of the coating. To achieve the desired set of properties, it is often sufficient to introduce a small amount of functional silica additive into the composition, based on the traditional polymer [3]. 
Among the factors influencing the properties of HOIC, an important role is played not only by the ratio of the initial components, but also by the polymeric matrix structure. The appearance of the interface, geometric constraints of the polymerization space and the growth of the polymer free volume due to addition of an inorganic component affect the physico-chemical and mechanical properties of composites [4].

It is known that the peculiarities of the structural-molecular organization of the polymer influence their thermomechanical properties [5]. The purpose of this work was to study the influence of the polymeric matrix structure in polymer-silica composites on their physical and chemical properties and the kinetics of polymerization till deep conversion.

\section{MATERIALS AND METHODS}

For research, two monomers of different structure were used: monomethacrylate 2-hydroxyethyl methacrylate (HEMA) $\mathrm{CH}_{2}=\mathrm{C}\left(\mathrm{CH}_{3}\right)-\mathrm{C}(\mathrm{O})-\mathrm{O}-\mathrm{CH}_{2}-\mathrm{CH}_{2}-\mathrm{OH}$ (P.A. purity, Aldrich) and dimethacrylate - oligoester acrylate MGF-9 $\quad \mathrm{CH}_{2}=\mathrm{C}\left(\mathrm{CH}_{3}\right)-\mathrm{C}(\mathrm{O})-$ $\left(\mathrm{CH}_{2} \mathrm{CH}_{2} \mathrm{O}\right)_{3}-\mathrm{O}-\mathrm{C}(\mathrm{O})-\mathrm{C}_{6} \mathrm{H}_{4}-\mathrm{C}(\mathrm{O})-\mathrm{O}-$ $\left(\mathrm{OCH}_{2} \mathrm{CH}_{2}\right)_{3}-\mathrm{C}(\mathrm{O})-\mathrm{C}\left(\mathrm{CH}_{3}\right)=\mathrm{CH}_{2}$ (P.A. purity, Aldrich). 2,2-dimethoxy-1,2-diphenylethane-1-on (IRGACURE 651) $\mathrm{C}_{6} \mathrm{H}_{5}-\mathrm{C}\left(\mathrm{OCH}_{3}\right)_{2}-\mathrm{C}(\mathrm{O})-\mathrm{C}_{6} \mathrm{H}_{5}$ was used as photoinitiator (P.A. purity, Fluka). For preparing of sol-gel system tetraethoxysilane (TEOS) $\mathrm{Si}\left(\mathrm{OC}_{2} \mathrm{H}_{5}\right)_{4}$ (ECOS-1, Russia), ethanol $\mathrm{C}_{2} \mathrm{H}_{5} \mathrm{OH}$ (P.A. purity) and orthophosphoric acid $\mathrm{H}_{3} \mathrm{PO}_{4}$ (P.A. purity) were used. Monomers were purified by mixing with pre-activated $\mathrm{Al}_{2} \mathrm{O}_{3}$ powder and subsequent centrifugation.

The composites were obtained by simultaneous joint photoinitiated polymerization of mixtures of liquid organic and inorganic components. The starting compositions were prepared by mixing of the sol-gel system TEOS: $\mathrm{H}_{2} \mathrm{O}: \mathrm{C}_{2} \mathrm{H}_{5} \mathrm{OH}: \mathrm{H}_{3} \mathrm{PO}_{4}$ with monomethacrylate (HEMA) and, in parallel, with dimethacrylate (MGF-9) at following ratio: $97.5: 2.5 ; 95: 5 ; 90: 10 ; 80: 20$ (vol.\%). In addition, pristine HEMA and MGF-9 were investigated for comparison. The content of photoinitiator in all cases was $2 \mathrm{~mol} \%$ per monomer. The solution of monomer and photoinitiator was mixed with prepared sol-gel system TEOS: $\mathrm{H}_{2} \mathrm{O}: \mathrm{C}_{2} \mathrm{H}_{5} \mathrm{OH}: \mathrm{H}_{3} \mathrm{PO}_{4}=2.2$ : $0.36: 4.08: 0.0072(\mathrm{ml})$ using a magnetic stirrer for $20 \mathrm{~min}$ at room temperature. The resulting compositions were placed into a glass tube using dosimeter, closed by a covering glass to prevent access of oxygen, and then subjected to photoinitiated polymerization under UV irradiation of a mercury-quartz lamp DRT-400 at the intensity of $48 \mathrm{~W} / \mathrm{m}^{2}$ until the polymerization process was completed. The obtained samples were kept in a drying oven at $40{ }^{\circ} \mathrm{C}$ for a week for the completion of sol-gel processes in the polymeric matrix. For thermomechanical analysis, all samples were prepared in the form of a cylinder with the diameter of $9.0 \mathrm{~mm}$ and the height of $10.0 \mathrm{~mm}$.

Thermomechanical analysis (TMA) of MGF-9 : TEOS samples, polymerized in block, was carried out at once. HEMA : TEOS samples were ground up to a powdery condition by means of a vibration mill, then pressed in a preheated mold at $110^{\circ} \mathrm{C}$ under the pressure of $150 \mathrm{~atm}$ and kept in press mold under pressure until it was cooled to the room temperature. For removal of internal stresses, the samples after pressing were kept in a drying oven at $t=80^{\circ} \mathrm{C}$ for $10 \mathrm{~h}$ and then TMA was performed.

Thermomechanical analysis of synthesized samples was carried out on a device for determining of polymer materials heat resistance "Heckert" (Medingen, Germany) in the mode of uniaxial compression under the load of $5.3 \cdot 10^{5} \mathrm{~N} / \mathrm{m}^{2}$ and the heating rate of $1.5^{\circ} \mathrm{K} / \mathrm{min}$. Deformation of the sample was determined using a zero-indicator with an accuracy of $0.01 \mathrm{~mm}$. The sample temperature during the experiment was measured using a standard small-inertial thermocouple TCC. TMA method reflects composite behavior under temperature and mechanical loading influence.

The kinetics of stationary photoinitiated polymerization of monomer-TEOS systems was investigated in thin films using a laser interferometer. $\quad 0.04 \mathrm{ml}$ of liquid HEMA/MGF-9 : TEOS photocomposition was placed by dosimeter into a glass mold, closed from oxygen access by a covering glass, and photopolymerized at room temperature and constant intensity of UV irradiation of $48 \mathrm{~W} / \mathrm{m}^{2}$ till deep conversion. Relative integral conversion $P$ was estimated as the ratio of the current contraction of photocomposition layer to the limiting contraction (at $t \rightarrow \infty$ ). The absolute measurement error of the linear shrinkage of composition is $2.24 \cdot 10^{-7} \mathrm{~m}$. The relative error of the experiment varies us dependent on the film 
thickness and is $2-10 \%$. The results of the experiment were depicted as integral kinetic curves "relative conversion $P$ - time $t$ (s)" and their differential anamorphoses. The statistical analysis of experimental kinetic curves was performed using ORIGIN program. In order to increase the assurance of the experimental data, 3-6 kinetic curves were obtained for each experimental condition, which were then averaged into the form of a single kinetic curve. It is related with the fluctuation sensitivity of the polymerization process, especially at the stage of auto-acceleration of polymer chain growth during polymerization [6].

\section{EXPERIMENTAL}

The obtained averaged integral and differential kinetic curves for polymerization of HEMA : TEOS and MGF-9 : TEOS systems are shown in Figs. 1, 2.

All integral kinetic curves of photomolymerization of the HEMA : TEOS system regardless of the composition content have a typical S-shape and consist of three stages: $1-$ a long, almost linear initial section; $2-\mathrm{a}$ short, but intensive section of autoacceleration; 3 - a long and slow section of autobraking. At bifunctional monomer (MGF-9) based system polymerization the separation of the solid polymer phase begins already at $\sim 1 \%$ conversion, so the kinetic curves of the process consist of only two sections: acceleration and auto-braking. These kinetic features of polymerization of mono- and dimethacrylates were described by the concept of microheterogeneity of photoinitiated polymerization process till deep conversion in variants of two reaction zones for polyfunctional (meth)acrylates and three reaction zones for monofunctional methacrylates [6]. The maximum speed $W_{0}$ of polymerization at the acceleration stage, corresponding conversion $P_{0}$ and time $t_{0}$ of its achievement were determined by the method of numerical differentiation of integral kinetic curves (Table 1).

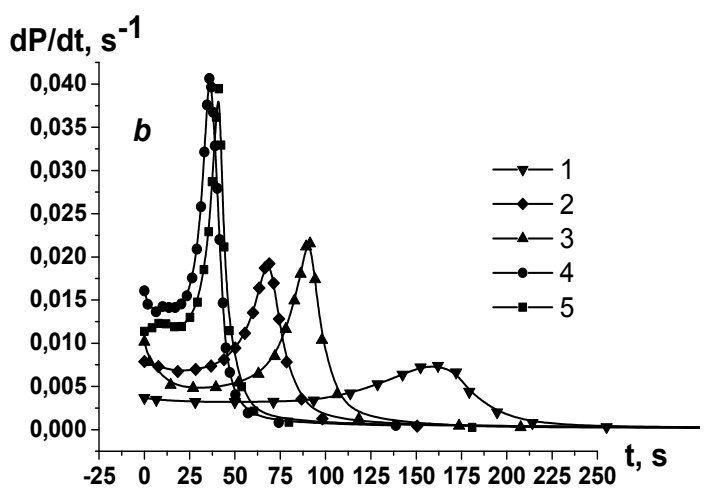

Fig. 1. Integral $(a)$ and differential $(b)$ kinetic curves of photoinitiated polymerization of HEMA : TEOS systems with different content of TEOS, vol. \%: $1-20 ; 2-10 ; 3-5 ; 4-2.5 ; 5-0$
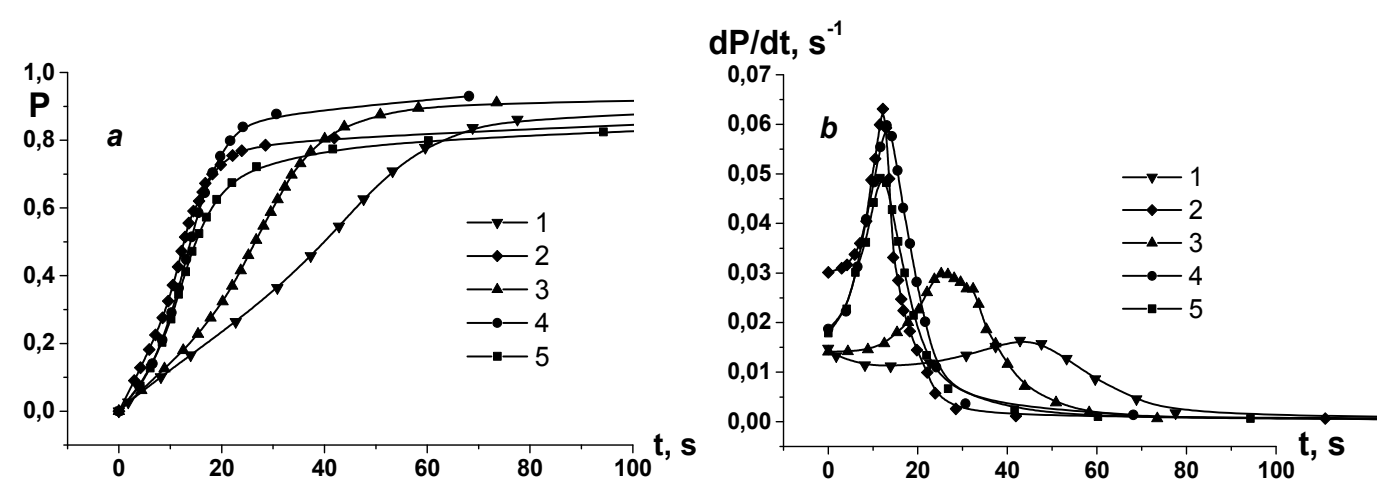

Fig. 2. Integral $(a)$ and differential $(b)$ kinetic curves of photoinitiated polymerization of MGF-9 : TEOS systems with different content of TEOS, vol. \%: $1-20 ; 2-10 ; 3-5 ; 4-2.5 ; 5-0$ 
Table 1. Kinetic parameters of polymerization of HEMA/MGF-9 : TEOS systems at different ratio of components

\begin{tabular}{cccccccc}
\hline \multirow{2}{*}{$\begin{array}{c}\text { Curve } \\
\text { number }\end{array}$} & $\begin{array}{c}\text { Composition content } \\
(\text { vol. } \%)\end{array}$ & \multicolumn{2}{c}{ HEMA : TEOS system } & \multicolumn{3}{c}{ MGF-9 : TEOS system } \\
\cline { 2 - 7 } & $80: 20$ & $\boldsymbol{W}_{\mathbf{0}}, \mathbf{s}^{-\mathbf{1}}$ & $\boldsymbol{P}_{\mathbf{0}}$ & $\boldsymbol{t}_{\mathbf{0}}, \mathbf{s}$ & $\boldsymbol{W}_{\mathbf{0}}, \mathbf{s}^{-\mathbf{1}}$ & $\boldsymbol{P}_{\mathbf{0}}$ & $\boldsymbol{t}_{\mathbf{0}}, \mathbf{s}$ \\
\hline 1 & $90: 10$ & 0.007 & 0.67 & 162 & 0.016 & 0.55 & 43 \\
2 & $95: 5$ & 0.022 & 0.69 & 91 & 0.063 & 0.47 & 12 \\
3 & $97.5: 2.5$ & 0.041 & 0.64 & 36 & 0.06 & 0.45 & 13 \\
4 & $100: 0$ & 0.04 & 0.65 & 41 & 0.05 & 0.34 & 12 \\
5 & & & & & & & \\
\hline
\end{tabular}

From the experimental results it follows that when the inorganic component is introduced into the system, one can observe a decrease in the rate of the photoinitiated polymerization of the monomer phase, regardless of monomer structure and this reduction is much larger than it would be in the case of the neutral dilution. This is evidenced by a sharp (2-4 times) increase in the time $t_{0}$ of reaching of the maximum polymerization rate (see Table 1).

For HEMA : TEOS systems, decreasing of the polymerization rate becomes noticeable already at low content of the inorganic component. At the same time, at small additions of the inorganic component ( 2.5 and 5.0 vol. \%) to MGF-9: TEOS systems kinetic curves and kinetic parameters of the process of polymerization practically do not differ from the same parameters for pristine MGF-9. This fact is especially noticeable for the ratio MGF-9 : TEOS $=97.5: 2.5$ vol. $\%$ (Fig. $1 b$ ). The acceleration of polymerization process for compositions with high concentrations of the inorganic component (10 and 20 vol. \%), regardless of monomer structure, is caused by the appearance of a new polymeric phase in the form of micrograins [7].

Conducted studies of the kinetics of photoinitiated polymerization of HEMA : TEOS and MGF-9 : TEOS systems till deep conversion showed a relationship between the values of the maximum polymerization rate, conversion, time of its achieving and the ratio monomer: TEOS in compositions.

It is known that the thermomechanical properties reflect the peculiarities of structural and molecular organization of polymers [5]. To determine the structural and molecular parameters of studied composites, an investigation of their mechanical behavior under the simultaneous action of mechanical loads and high temperatures thermomechanical analysis of the obtained composites HEMA/MGF-9 : TEOS with different content of the inorganic component was carried out.

The results of thermomechanical analysis of HEMA : TEOS and MGF-9 : TEOS composites are presented in the form of the dependence of the relative deformation $\varepsilon\left(\varepsilon=\Delta h / h_{0}\right.$, where $\Delta h-$ the sample deformation, $h_{0}$ - the initial size of the sample) on the temperature (Figs. 3, 4).

The difference in the form of the obtained TMA-curves is connected, first of all, with the polymer structure in the composite. For linear polymers (Fig. 3), two temperature regions are clearly distinguished: the initial section of glassy state and the region of high elasticity, while for cross-linked polymers (Fig. 4), apart from above mentioned regions, a section of thermomechanical flow appears. In addition, the obtained TMA-curves for HEMA : TEOS composites with different content of the inorganic component are similar. At the same time, although the obtained thermomechanical curves of the samples of MGF-9: TEOS composites (Fig. 4) generally have the form typical for cross-linked polymers, however, the form of composite TMA-curve is markedly different from that of pristine MGF-9 polymer.

On TMA-curves of the studied composites typical for polymers initial abrupt rising section is identified that corresponds to the structural transition of polymer composite from glassy state into highly elastic state - $\alpha$-relaxation process associated with "disbraking" of kinetic segments of polymeric matrix under the influence of temperature [5]. For MGF-9 : TEOS composite introduction of the inorganic component into the system leads to the appearance of falling branch on TMA-curve. Negative values of $\varepsilon$ for the investigated samples indicate the presence of the internal pressure, the 
value of which is higher than the applied external load, associated primarily with the method of sample preparation for TMA. So when heated to the polymer softening temperature, these internal stresses relax and sample sizes increase. As at temperature increase high elastic deformation of

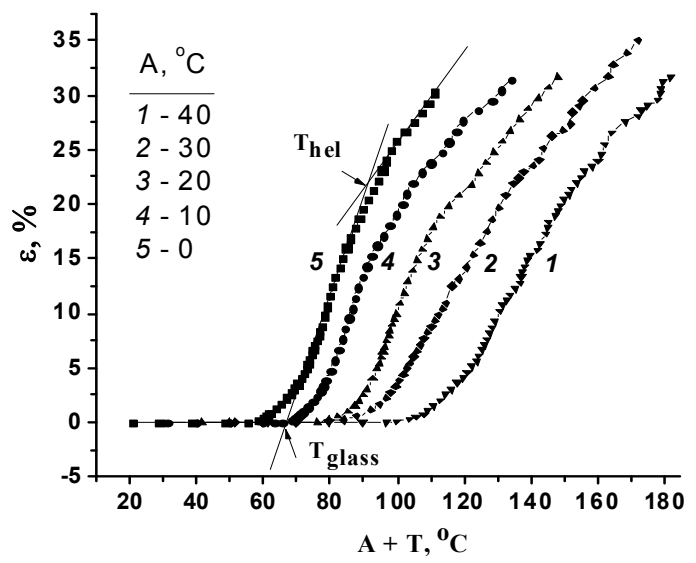

Fig. 3. Thermomechanical curves of HEMA : TEOS samples with different content of TEOS, vol. \%: $1-20 ; 2-10 ; 3-5 ; 4-2.5 ; 5-0$. For greater visuality, curves $2-5$ are shifted along abscissa axis by the value of $A$ with respect to the curve 5

Composites transition temperatures into high elastic state $\left(T_{h e l}\right)$ and a state of thermomechanical fluidity $\left(T_{t m f}\right)$ were defined as the intersection points of straight-line segments that coincide with the corresponding sections of thermomechanical curve. The accuracy of $T_{\text {glass }}$, $T_{\text {hel }}$ and $T_{\text {tmf }}$ determination is $\pm 2 \mathrm{~K}$.

TMA method, apart from determination of characteristic temperatures $\left(T_{\text {glass }}, T_{\text {hel }}\right.$ and $\left.T_{\text {tmf }}\right)$ of composites, allows us to evaluate physicomechanical, structural and molecular characteristics of composites in the form of high elasticity equilibrium modulus $E_{\infty}\left(\mathrm{N} / \mathrm{m}^{2}\right)$, molecular mass of kinetic segment (macrochain segment between nodes of structural network) of composites $M_{s}(\mathrm{~g} / \mathrm{mol})$ and segment number (effective cross-linking nodes) per volume unit $n_{s}\left(\mathrm{~mol} / \mathrm{m}^{3}\right)$.

In the framework of the statistical theory of molecular network elasticity of cross-linked polymers, the dependence of cross-linking density $\left(M_{s}\right)$ on high-elasticity modulus $\left(E_{\infty}\right)$ is described by the equation [8]

$M_{s}=\frac{3 \gamma \rho R T v}{E_{\infty} v_{0}}$, the polymer occurs independently under external factors influence or as a result of internal forces, the glass transition temperature of the polymer $T_{\text {glass }}$ can be determined by extrapolation of linear part of this section on the temperature axis [5].

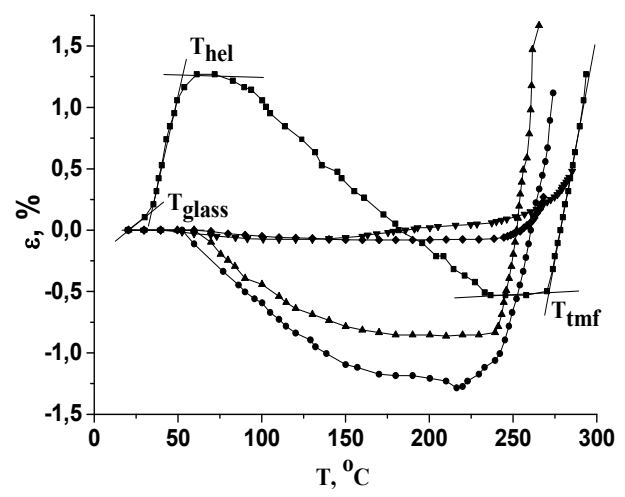

Fig. 4. Thermomechanical curves of MGF-9 : TEOS samples at different ratio of components, vol. \% : $1-80: 20 ; 2-90: 10 ; 3-95: 5 ; 4-97.5: 2.5$; $5-100: 0$

where $M_{s}$ - the molecular mass of kinetic segment; $E_{\infty}-$ high elasticity modulus; $\gamma-$ a structural coefficient dependent on the network nature and topology; $\rho$ - sample density; $v_{o}$ - the total number of transverse bonds; $v$ - the number of physically effective bonds that form a spatial structure; $R$ - the universal gas constant; $T$ - the temperature of transition of the material into a high elastic state, $\mathrm{K}$.

Quantitative verification of this correlation is rather complicated, since the fraction of functional groups that participate in the formation of physically active relationships is unknown. Even greater uncertainty is associated with the estimation of the structural coefficient $\gamma$. Assuming that $E_{\infty} \leq 6 \cdot 10^{7} \mathrm{~N} / \mathrm{m}^{2}$, we can accept $v=v_{0}, \gamma=1$ [9]. In this case, the calculation using equation (1) is considerably simplified.

High-elastic modulus $E_{\infty}$ can be calculated by the equation

$E_{\infty}=\frac{P}{F \cdot \varepsilon}$,

where $P$ - the load on the sample, N; $F$ - the cross-sectional area of the sample to which the 
force is applied, $\mathrm{m}^{2} ; \varepsilon$ - relative deformation of the sample in high elasticity region.

$M_{s}$ is a measure of cross-linking density, which is, respectively, a factor that determines the whole set of physical and mechanical properties of polymer (strength, hardness, relaxation properties, etc.). The $M_{s}$ value allows to estimate the number of segments (effective cross-linking nodes) per volume unit $n_{s}\left(\mathrm{~mol} / \mathrm{m}^{3}\right)$ :

$n_{s}=\frac{\rho}{M_{s}}$.

The average density $\rho$ was determined as the mass of volume unit of the sample, dried till a constant mass, in the natural state. Since the sample has the correct geometric shape (cylinder), its volume was determined by measuring of the length, width and diameter using a caliper (accuracy was $0.05 \mathrm{~mm}$ ), and the sample mass was defined by weighing the samples on an analytical balance (accuracy was $0.0002 \mathrm{~g}$ ).

The obtained values of the characteristic parameters of the investigated organic-mineral composites are given in Tables 2 and 3 .

The analysis of TMA-curves and the study of the dependences of the thermomechanical properties of the obtained HOIC on the content of the inorganic component in the systems HEMA/MGF-9 : TEOS (see Fig. 2, Table 2) indicates that there are different dependences of the basic thermomechanical parameters of the composites on the composite content at different polymer structure.

Thus, at small concentrations of inorganic component (2.5 and 5 vol. \%) in HEMA:TEOS systems the equilibrium modulus of high elasticity $E_{\infty}$ increases is due to decrease in the molecular mass of the kinetic segment $M_{s}$ and an increase of the network nodes concentration $n_{s}$. However, at higher concentrations of inorganic component (10 and 20 vol. \%) in composites, the opposite situation can be observed: the modulus of high elasticity $E_{\infty}$ decreases, the molecular mass of the kinetic segment increases, the concentration of the network nodes concentration decreases. An introduction of inorganic component into the system up to $10 \mathrm{vol} . \%$ practically does not affect the value of the glass transition temperature of the composites compared to the pristine polymer, at the same time, $T_{h e l}$ increases with the increase in the number of TEOS in the system.

Table 2. Thermomechanical properties and structural and molecular parameters of composites synthesized on the basis HEMA : TEOS system

\begin{tabular}{|c|c|c|c|c|c|c|}
\hline \multicolumn{2}{|c|}{ HEMA : TEOS system } & \multirow{2}{*}{$\begin{array}{c}T_{\text {glass }}, \\
\mathrm{C}\end{array}$} & \multirow{2}{*}{$\underset{\substack{T_{h e l} \\
\mathrm{C}}}{T^{\prime}}$} & \multirow{2}{*}{$\begin{array}{c}E_{\infty} \cdot 10^{-6} \\
N / \mathbf{m}^{2}\end{array}$} & \multirow{2}{*}{$\begin{array}{c}M_{s} \cdot 10^{-3} \\
\mathrm{~g} / \mathrm{mol}\end{array}$} & \multirow{2}{*}{$\begin{array}{l}n_{s} \cdot 10^{-3} \\
\mathrm{~mol} / \mathrm{m}^{3}\end{array}$} \\
\hline Sample & vol. $\%$ & & & & & \\
\hline 1 & $80: 20$ & 74 & 110 & 2.22 & 5.362 & 0.188 \\
\hline 2 & $90: 10$ & 64 & 105 & 2.43 & 4.817 & 0.207 \\
\hline 3 & $95: 5$ & 65 & 88 & 3.34 & 3.329 & 0.300 \\
\hline 4 & $97.5: 2.5$ & 65 & 86 & 3.12 & 3.564 & 0.282 \\
\hline 5 & HEMA & 67 & 91 & 2.72 & 4.122 & 0.242 \\
\hline
\end{tabular}

Table 3. Thermomechanical properties and structural and molecular parameters of composites synthesized on the basis of MGF-9 : TEOS system

\begin{tabular}{|c|c|c|c|c|c|c|c|}
\hline \multicolumn{2}{|c|}{ MGF-9 : TEOS system } & \multirow{2}{*}{$\begin{array}{c}T_{\text {glass }}, \\
\text { C }\end{array}$} & \multirow{2}{*}{$\boldsymbol{T}_{\text {hel }}$, } & \multirow{2}{*}{$T_{t m f}$} & \multirow{2}{*}{$\begin{array}{c}E_{\infty} \cdot \mathbf{1 0} \mathbf{-}^{\mathbf{8}}, \\
\mathrm{N} / \mathbf{m}^{2}\end{array}$} & \multirow{2}{*}{$\begin{array}{c}M_{s}, \\
\mathrm{~g} / \mathrm{mol}\end{array}$} & \multirow{2}{*}{$\begin{array}{l}n_{s} \cdot 10^{-3} \\
\mathrm{~mol} / \mathrm{m}^{3}\end{array}$} \\
\hline Sample & vol. \% & & & & & & \\
\hline 1 & $80: 20$ & 45 & 116 & 261 & 4.90 & 24.34 & 50.53 \\
\hline 2 & $90: 10$ & 60 & 130 & 252 & 6.43 & 19.06 & 64.01 \\
\hline 3 & $95: 5$ & 61 & 129 & 246 & 0.68 & 178.33 & 6.79 \\
\hline 4 & $97.5: 2.5$ & 54 & 145 & 242 & 0.48 & 271.37 & 4.61 \\
\hline 5 & MGF-9 & 32 & 57 & 264 & 0.35 & 289.12 & 4.25 \\
\hline
\end{tabular}

It indicates that at adding of small amounts of TEOS (2.5 and 5 vol. \%), the inorganic phase formed as nanoparticles is embedded into the defective or weakly cross-linked areas of polymer matrix [10-11], so an effect of "small additives" takes place [12]. Due to introduction of small amounts of inorganic components, decrease of matrix defectivity occurs, allowing 
an increase in rigidity of cured polymer structure. At higher concentrations of inorganic component (10 and $20 \mathrm{vol} . \%)$ deterioration of mechanical properties of composites (elasticity modulus reduction and growth of kinetic segment molecular mass) is related with formation of three-dimensional network of inorganic component, accompanied by microdisposition of formed phases [13].

For a composite based on a spatially crosslinked polymer (MGF-9: TEOS), the influence of the inorganic component is more pronounced. Since, according to the concept of microheterogeneity of radical polymerization, polymer MGF-9 has a granular structure where polymeric grains are bound together into a single frame structure with hydrogen bonds or individual monomer molecules $[6,14,15]$, the introduction of a small amount of inorganic component into MGF-9: TEOS system ( 2.5 vol. \% TEOS) leads to a significant increase in the glass transition temperature compared to that of pristine polymer $\left(32^{\circ} \mathrm{C}\right.$ to $\left.57^{\circ} \mathrm{C}\right)$. Simultaneously, one can observe a decrease in the length of the internode segment of the polymeric matrix and a increase in the value of high elasticity modulus. Thus, reducing of the matrix defectivity and the appearance of the "near" order in the structure leads to an increase in the stiffness of the structure and deceleration of the rate of $\alpha$-relaxation processes in polymeric matrix.

Increase of TEOS amount in MGF-9 : TEOS system up to 5 vol. \% changes the thermomechanical properties of the composite insignificantly. In this case, further increase of high elasticity modulus and the reduction of internode segment length, the increase of the glass transition temperature $\left(T_{\text {glass }}\right)$ and the thermal fluidity $\left(T_{t m f}\right)$ at simulteneous decreasing of high elasticity temperature of the composite $\left(T_{h e l}\right)$ is observed.

Further growth of the concentration of inorganic component up to $10 \mathrm{vol}$ \% stabilizes the glass transition and high elasticity temperature of the composite, but there is a significant (by an order) increase in the value of high elasticity modulus and a decrease (by an order) of the molecular mass of kinetic segment. Such changes in parameters probably indicate the formation of a three-dimensional network of inorganic component, which leads to a marked increase in the rigidity of polymeric matrix.
Simultaneously, the growth of the crosslinking degree with increasing of concentration of inorganic component leads to a limitation of the mobility of kinetic segments of polymeric matrix and, relatively, to reduction of the internal stresses in the system, which is confirmed by the smallest value of sample deformation (Fig. 4, sample 2).

At high degree of filling of the composite with inorganic component (TEOS 20 vol. \%) microheterogenization of the system occurs, as it is indicated by the decrease in the value of high elasticity modulus and the growth of the molecular mass of kinetic segment. The microstratification of the formed phases consisting of three-dimensional polymers leads to a decrease in the glass transition and high elasticity temperatures of the composite. The destruction of the bonds between them occurs at different temperatures, it is evidenced by the appearance of a jump-like growth of the deformation on TMA-curve (Fig. 4, sample 1).

Spatially-structured polymers can be characterized by the presence of an expressed high elasticity plateau which is caused by the formation of spatial network blocking the mobility of polymer macromolecules. The length of the plateau points to the increase in rigidity of the frame, which hinders the transition of polymeric matrix into the elastic-flow state. For pristine monomer MGF-9 in this temperature range the decrease in relative deformation up to change of the sign is observed. Increasing of the temperature leads to a weakening of the links between individual dense cross-linked polymer grains, increasing of their mobility and gradual reduction of internal stresses in individual grains of polymer chain, which causes a sharp increase in the resistance of polymeric matrix to external load $[6,14,16]$. The appearance of inorganic component changes the form of high elasticity section of MGF-9: TEOS composite. This is correlated with the shift of $T_{\text {tmf }}$ values for MGF-9 : TEOS composites towards higher temperatures with increasing of inorganic phase amount from 2.5 up to $20 \mathrm{vol} \% \%$. That is, deformation in the range of $100-200{ }^{\circ} \mathrm{C}$ corresponds with softening of the polymeric component of the composite; at temperatures above $200{ }^{\circ} \mathrm{C}$ - with partial destruction of inorganic network.

At temperatures above $230-250{ }^{\circ} \mathrm{C}$, a sharp increase in deformation is observed, which 
corresponds to the region of irreversible deformations, the flow of the composite, related with the destruction of not only interchain bonds, but also with the destruction of macromolecules. As the results show, an increase in the amount of inorganic phase for MGF-9: TEOS composites leads to an increase in $T_{t m f}$, indicating an increase of the role of inorganic component in the deformation stability of the polymer composite under mechanical and thermal loading.

\section{DISCUSSION}

The results showed that the polymer structure and the amount of inorganic component in the system have a strong influence on the properties of composites based on organic and inorganic polymers.

For composites based on linear polymer HEMA, at in situ synthesis, formation of covalent and hydrogen bonds between silanol and carbonyl groups of inorganic and organic components of the system is possible. The amount and intensity of these bonds depend inorganic component content. The addition of the small amount of inorganic component in which the fraction of silica is compatible with polymeric matrix leads to an increase in the temperature stability and mechanical properties of the composite. With the increase in the amount of inorganic component, a hybrid system based on HEMA : TEOS acquires a heterogeneous character, i.e. the inorganic phase is formed in material. The heterogeneity of the system, which appears already at 10 vol. \% TEOS, causes difficulties in realization of equilibrium conformations of macromolecules and leads to changes of the free volume in a polymeric material. Such composite morphology seems to be the reason of deterioration of physical and chemical properties, increasing with the increase of inorganic component content [14].

For ester MGF-9 the presence of carbonyl groups in the chain also leads to the formation of bonds between the organic and inorganic components of the system [4]. However, when cross-linked polymer with small amount of inorganic component is forming, the formation is possible of a structure in which inorganic molecules or their agglomerates are captured in organic macrostructure [13]. Inorganic component introduction into polymeric matrix in the form of nanoparticles primarily in microareas with lower density - weakly cross-linked and defective areas, identifies reinforcing effect on the properties of the polymer and facilitates the effect of small additives [10,11], with virtually no effect on the polymerization process of the polymer.

However, increase of the quantity of inorganic component till 5 vol. \% leads to the change of composite morphology. For such content, the allocation of the inorganic component into a separate phase in the form of clusters is possible [17], leading to the appearance of the transitional disordered organic-silica structure. The presense of inorganic component can also hinder polymer monolithization, what can explain the decrease of the thermal flow temperature as compared to pristine MGF-9.

Unlike composites based on linear polymers (HEMA : TEOS), the growth of TEOS amount till 10 vol. \% leads to formation of a cross-linked network of the inorganic component - so-called interpenetrating structure having a high level of system order. The growth of the regularity of the copolymer chain structure leads to an increase in the interaction of the elements of the macromolecular coil, that contributes to the growth of its density and, as a result, to increase of the thermomechanical properties of the composite [18]. Such composite has by higher values of high elasticity modulus, cross-links density and high heat resistance as compared to other composites.

Further growth of the inorganic phase is accompanied by microstratification of the phases, which, as in the case of HEMA : TEOS, leads to a decrease in the thermal stability of the composite.

\section{SUMMARY}

In this paper it is shown that the thermal stability of organic-inorganic composites depends not only on the amount of inorganic component, but also on the polymer structure. At the same time, for a system with linear polymer HEMA the plot "thermal composite property TEOS content" has a linear form, while for the system with a spatially cross-linked polymer MGF-9 it includes an extremum which is related to the structure of the formed composite. 


\title{
Вплив будови полімерної матриці на кінетичні та термомеханічні властивості органо-неорганічних композитів на основі ТЕОС
}

\author{
Г.І. Хованець, О.Ю. Макідо, Ю.Г. Медведевських, І.Ю. Свчук \\ Відділення фізико-хімії горючих копалин Інституту фізико-органічної хімії і вуглехімії \\ ім. Л.М. Литвиненка Національної академї̈ наук Украӥни \\ вул. Наукова, 3а, Львів, 79060, Україна, khovanets_galyna@ukr.net
}

\begin{abstract}
Досліджено вплив будови полімерної матриці гібридних органо-неорганічних композитів на основі системи моно- або диметакрилату та тетраетоксисилану, а також їх складу на термомеханічні властивості і молекулярну структуру та кінетику полімеризації до глибоких конверсій. Одержано кінетичні та термомеханічні криві як композитів, так $і$ чистих полімерів, за якими визначено кінетичні параметри полімеризації та характеристичні температури $i$ термомеханічні структурно-молекулярні параметри зразків. Показано, щзо введення неорганічного наповнювача у матриию монометакрилату сприяє лінійному зростанню термомеханічної стійкості матеріалу, а у матрицю диметакрилату - характеризується наявністю екстремуму. 3'ясовано, щзо покращені термомеханічні властивості мають композити ГЕМА:ТЕОС $=95: 5$ об. \% та МГФ-9:ТЕОС $=90: 10$ об. \%.
\end{abstract}

Ключові слова: органо-неорганічний композит, золь-гель система, фотоініційована полімеризація, кінетика до глибоких конверсій, термомеханічний аналіз

\section{Влияние строения полимерной матрицы на кинетические и термомеханические свойства органо-неорганических композитов на основе ТЭОС}

\section{Г.И. Хованец, Е.Ю. Макидо, Ю.Г. Медведевских, И.Ю. Евчук}

Отделение физико-химии горючих ископаемых Института физико-органической химии и углехимии им. Л.Н. Литвиненко Национальной академии наук Украинь ул. Научная, 3а, Львов, 79060, Украина, khovanets_galyna@ukr.net

Исследовано влияние строения полимерной матрицы гибридных органо-неорганических композитов на основе системы моно- или диметакрилата и тетраэтоксисилана, и их состава на термомеханические свойства и молекулярную структуру и кинетику полимеризации до глубоких конверсий. Получены кинетические и термомеханические кривые как композитов, так и чистых полимеров, по которым определены кинетические параметры полимеризации $u$ характеристические температуры $u$ термомеханические структурно-молекулярные параметры образцов. Показано, что введение неорганического наполнителя в матрицу монометакрилата способствует линейному росту термомеханической устойчивости материала, а в матрииу диметакрилата - характеризуется наличием экстремума. Установлено, что улучшенные термомеханические свойства имеют композиты ГЭМА:ТЭОС = 95:5 об. \% и МГФ-9:ТЭОС $=90: 10$ об. \%.

Ключевье слова: органо-неорганический композит, золь-гель система, фотоинициированная полимеризаџия, кинетика до глубоких конверсий, термомеханический анализ

\section{REFERENCES}

1. Shilova O.A., Shilov V.V. Nanocomposite oxide and hybrid organo-inorganic materials obtained by the sol-gel method. Synthesis, properties, application. Nanosistemi, Nanomateriali, Nanotehnologii. 2003. 1(1): 9. [in Russian].

2. Poole C., Owens F. Nanotechnology. (Moscow: Tekhnosfera, 2006). [in Russian].

3. Revo S.L., Avramenko T.G., Dashevskyi M.M., Ivanenko E.A., Boshko O.I. Effect of the filler dispersity on mechanical and electrical properties of the fluoroplastic-thermally exfoliated graphite nanocomposite material. Polymer J. 2013. 35(2): 186. [in Ukrainian]. 
4. Hua Z., Shishan W., Jian S. Polymer/silica nanocomposites: preparation, characterization, properties and applications. Chem. Rev. 2008. 108(9): 3893.

5. Teitelbaum B.Y. Thermomechanical analysis of polymers. (Moscow: Nauka, 1979). [in Russian].

6. Berlin A.A., Korolev G.V., Kefeli T.Y., Sivergin Y.M. Acrylic oligomers and materials based on them. (Moscow: Chemistry, 1983). [in Russian].

7. Medvedevskikh Y., Khovanets' G., Yevchuk I. Kinetic model of photoinitiated copolymerization of monofunctional monomers till high conversions. Chem. Chem. Technol. 2009. 3(1): 1.

8. Zakordonskiy V.P., Gnatyshyn Y.S., Soltys M.N. Influence of highly disperse mineral fillers on the thermal stability of epoxy composites. Russ. J. Appl. Chem. 1988. 71(9): 1524.

9. Petko I.P., Batog A.G., Zaitsev Y.S. The influence of the chemical structure of epoxyoligomers on the thermal and thermal stability of polymers. Composite Polymer Materials. 1987. 34: 10. [in Russian].

10. Pomohailo A.D. Hybrid polymer-inorganic nanocomposites. Russ. Chem. Rev. 2000. 69(1): 60.

11. Zhil'tsova S.V. Anhydride cured epoxy-silica nanocomposites obtained via the sol-gel method. Bull. Donetsk Nation. Univers. Ser. A: Nat. Sci. 2014. 18(1): 144. [in Ukrainian].

12. Zakordonskiy V., Skladanyuk R., Tykhovetskiy A. Processes of formation and thermomechanical properties of filled epoxy polymers. Visn. Lviv Univ. Ser. Khim. 2003. 43: 190. [in Ukrainian].

13. Pavlyuchenko V.N., Sorochinskaya O.V., Khaikin S.Y., Fedorov S.P., Sosnov E.A., Pesetskii S.S., Ivanchev S.S. Organo-inorganic polymer mesh based on reactive copolymers of $n$-butyl methacrylate and 3-(trimethoxysilyl) propyl methacrylate. Russ. J. Appl. Chem. 2007. 80(1): 94.

14. Volkova M.V., Bel'govskiy I.M., Golikov I.V., Semyannikov V.A., Mogilevich M.M., Indeykin E.A. Light scattering study of formation of microheterogeneous structure of network polymers on the basis of oligoester acrylate. Polymer Sci. A. 1987. 28(3): 435. [in Russian].

15. Semyannikov V.A., Prokhorov A.L., Golikov I.V., Bel'govskiy I.M., Kastorskiy L.P. Local glass transition in the course of formation of microheterogeneous structure of network polymer on the basis of dimethacrylate triethylene glycol. Polymer Sci. A. 1989. 31(8): 1602. [in Russian].

16. Zakordonskiy V.P., Aksimentyeva E.I., Martyniuk G.V. Thermochemical and kinetic features of curing epoxyamine compositions in the presence of highly dispersed fillers. Composite Polymer Materials. 1989. 43: 25. [in Russian].

17. Dolbin I.V., Kozlov G.V., Zaikov G.E. The structural stabilization of polymers: Fractal Models. (Moscow: Academy of Natural Science, 2007). [in Russian].

18. Ivanchev S.S., Mesh A.M., Reichelt N., Khaikin S.Y., Hesse A., Myakin S.V. Preparation of nanocomposites by alkoxysilane hydrolysis in a polypropylene matrix. Polymer Sci. A. 2002. 44(6): 996. [in Russian]. 